\title{
Variability in Pyricularia oryzae from different rice growing regions of Tamil Nadu, India
}

\author{
Priya Vanaraj ${ }^{1}$, Saveetha Kandasamy ${ }^{1,3 \star}$, Sankaralingam Ambalavanan ${ }^{1}$ Rabindran \\ Ramalingam ${ }^{1}$ and Robin Sabariyappan ${ }^{2}$
}

\author{
${ }^{1}$ Department of Plant Pathology, Tamil Nadu Agricultural University, Coimbatore, Tamil Nadu, India. \\ ${ }^{2}$ Department of Rice, Tamil Nadu Agricultural University, Coimbatore, Tamil Nadu, India. \\ ${ }^{3}$ Department of Environmental Sciences, Faculty of Agriculture, Dalhousie University, Nova Scotia, Canada.
}

Accepted 12 June, 2013

\begin{abstract}
Potato dextrose and malt extract agar were found to be suitable for culturing different isolates of Pyricularia oryzae. Colonies of $P$. oryzae appeared as white on oat meal, rice polish and malt extract agar, grey on potato dextrose agar and whitish grey on rice agar. Spore induction was hastened on maize stem pieces than on rice and Panicum repens. Spore density on maize was $3420 / \mathrm{ml}$ of water as against $500 / \mathrm{ml}$ on $P$. repens. When spores of 11 isolates of $P$. oryzae were compared, conidia of the isolate from Pennisetum purpureum were significantly bigger than the other isolates. The spores of rice isolates from Erode and Gopichettipalayam were significantly smaller in length and width. Fingerprinting of 11 isolates of $P$. oryzae by retrotransposon - microsatellite amplified polymorphism (REMAP) showed a high level of variability and polymorphism among them. Phylogenetic analysis using REMAP markers grouped out one rice isolate from others. Two isolates of Tirunelveli region were grouped together like Erode and Gopichettipalayam isolates. Isolates causing leaf and neck blast showed $52.9 \%$ similarity. Isolates from Coimbatore and Gudalore were $32.7 \%$ similar; likewise two non-rice host isolates were grouped together with $27.6 \%$ similarity.
\end{abstract}

Key words: Variability, culture media, rice blast, Pyricularia oryzae, retrotransposon, microsatellite.

\section{INTRODUCTION}

Rice (Oryza sativa L.) is the staple food crop supplying nearly $23 \%$ of the per capita energy for six billion people worldwide and also fast becoming the model plant for monocot species in molecular biology and genomics studies (Jo et al., 2007). Among the diseases of rice, blastincitedby Pyriculariaoryzae(teleomorph:Magnaporthe oryzae) is the most serious disease in all rice growing regions of Tamil Nadu (Chadha and Gopalakrishna, 2005a) and blast outbreaks have been a serious threat to rice production worldwide (Koutroubas et al., 2009). Each year $P$. oryzae was reported to destroy rice enough to feed an estimated 60 million people and $50 \%$ of production could be lost in rice field moderately affected by blast
(Barman and Chattoo, 2005). Blast continues to pose a threat to the yield potential in rice cultivars in all the rice ecosystems (Annon., 1975-2005) in India.

Different species of Magnaporthe grisea cause blast disease on a wide range of gramineous plant hosts. Recently, based on phylogenetic analyses and mating tests isolates from grasses including rice were named as $M$. oryzae and isolates from crabgrass were separated from the species complex and named $M$. grisea (Choi et al., 2013). Magnaporthe oryzea (T.T. Herbert) Yaegashi \& Udagawa (anamorph = Pyricularia oryzae (Cooke) Sacc.) causes disease on more than 50 graminaceous species including important food crops such as rice (Tosa 
et al., 2004). Rice blast is a serious concern in temperate areas as well as in tropical uplands, such as those found in West Africa, Iran (Mousanejad et al., 2010), Malaysia (Rahim, 2010) and the savannas of South America (Bonman et al., 1989). Blast affects $12 \%$ of the total area of Rice cultivation in Indonesia (BPS, 2008). Blast was first recorded in India during 1913 and a devastating epidemic occurred in 1919 in the Tanjore delta of Tamil Nadu (Padmanabhan, 1965). Since its first appearance, the disease has been reported to occur in different regions of India (Padmanabhan et al., 1970; Singh et al., 2004; Rathour et al., 2004a). Yield reductions are drastic when caused by panicle blast which reduces the thousand grain weight, the percentage of ripe spikelet, and the percentage of fully mature grains (Teng et al., 1990). Infection of panicle base by the blast pathogen until 20 days after heading was found to cause more than 50 per cent of yield loss as observed by Shim et al., 2005. In India, yield loss due to blast could be as high as $50 \%$ when the disease attains an epidemic proportion (Lavanya and Gnanamanickam, 2000). In Andhra Pradesh, when the damage from natural epidemics of blast of rice was examined during wet seasons from 1995-1997 in three rice growing districts, disease prevalence at levels above the economic threshold ranged from 14 to $27 \%$ and the yield loss was about $27-35 \%$ (Rajarajeswari and Muralidharan, 2006).

Blast fungus is reported to be highly variable $(\mathrm{Ou}$, 1985; Kumar and Singh, 1995). Blast symptoms on leaves begin as gray-green and water-soaked lesions, with dark-green borders once the spots are completely expanded (Reis and Casa, 2005). The structure and dynamics of the population of $P$. oryzae need to be understood thoroughly if resistant genes are to be utilized ultimately to implement the strategies for management of blast. Virulence studies using host differentials are labour intensive and are further confounded by inoculation techniques and environmental conditions. In this regard, molecular methods have become alternative tools to characterize isolates of the blast pathogen (Babujee and Gnanamanickam, 2000). Genome fingerprinting has a major role in characterizing the population structure of fungi and further to study their variability (Chadha and Gopalakrishna, 2005a). Hence, an investigation was made to know the variability of $P$. oryzae isolates of rice and non-rice hosts collected from the major rice growing tracts of Tamil Nadu. The study also included testing culture media suited for the growth and sporulation of the fungus.

\section{MATERIALS AND METHODS}

\section{Source of isolates and pathogen isolation}

Samples of rice infected with leaf were collected from eight rice growing tracts of Tamil Nadu viz., Coimbatore, Erode, Gopichetti- palayam, Gudalore, Pakkapatti (Tirunelveli dt), Veeranam (Tirunelveli dt), and Thoothukudi. From Sathyamangalam, samples were collected from both leaf and neck infections. Besides rice, samples were also obtained from Echinochloa colonum and Pennisetum purpureum.

\section{Isolation of pathogen}

Blast lesions were surface sterilized with $0.1 \%$ mercuric chloride for $1 \mathrm{~min}$ and placed over clean glass slides kept in sterile Petri dishes padded with moist cotton. The Petri dishes were incubated for $48 \mathrm{~h}$ at room temperature $\left(28 \pm 2^{\circ} \mathrm{C}\right)$. Single conidia were identified from the sporulating lesions using a stereomicroscope and aseptically transferred to potato dextrose agar (PDA) slants for maintenance. The causal organism was identified as Pyricularia oryae based on the spore morphology.

\section{Media suitable for culturing Pyricularia oryzae}

The Coimbatore isolate of $P$. oryzae was grown on PDA for 10 days at room temperature. From the margin of actively growing fungus, 5-mm discs were plugged out. Sterile Petri dishes containing PDA, oat meal agar, rice agar, rice polish agar and malt extract agar were inoculated each with a single 5-mm disc of the fungus and incubated at room temperature for 30 days. Four replications were maintained for each medium. The fungal growth was measured at 5 -day-intervals until 30 days. Further, the colony characters of the single isolate on different media were recorded on $30^{\text {th }}$ day. All the 11 isolates were grown on PDA and their colony morphology was observed.

\section{Spore induction on stem bits}

The stem bits from maize, rice (20-day old crop) and $P$. repens were collected from the field and cut into small pieces of $1 \mathrm{~cm}$ in length. 15 pieces were placed in $50 \mathrm{ml}$ Erlenmyer flasks and sterilezed at a pressure of $1.4 \mathrm{~kg} / \mathrm{cm}^{2}$ for $1 \mathrm{~h}$ and $30 \mathrm{~min}$. Each flask was inoculated with two $5-\mathrm{mm}$ dia mycelial discs of the Coimbatore isolate and incubated for 15 days at room temperature. Three stem pieces were sampled at 5,10 and 15 days after inoculation (DAI). Each stem piece was placed in a test tube containing $1 \mathrm{ml}$ of sterile water, shaken well to dislodge the spores and decanted. The spore concentration was assessed using a haemocytometer.

\section{Measurement of spore size}

All the 11 isolates of $P$. oryzae were multiplied on maize stem bits for 15 days and spores were collected as mentioned earlier. The length and width of 10 spores were measured for each isolate using a micrometer.

\section{Variability studies using molecular markers}

\section{Extraction of total DNA}

Total DNA was extracted from the 11 isolates of $P$. oryzae. For DNA extraction, isolates were grown in $100 \mathrm{ml}$ of potato dextrose broth for four days at room temperature $\left(28 \pm 2^{\circ} \mathrm{C}\right)$. Mycelial mat was filtered, dried and $2 \mathrm{~g}$ of the mat was ground to a fine powder using liquid nitrogen. Powdered mycelia were vortexed in pre-warmed lysis buffer (10 mM Tris (pH: 8.5), $250 \mathrm{mM} \mathrm{NaCl}, 0.5 \mathrm{mM}$ EDTA and 


\section{0th DAI}

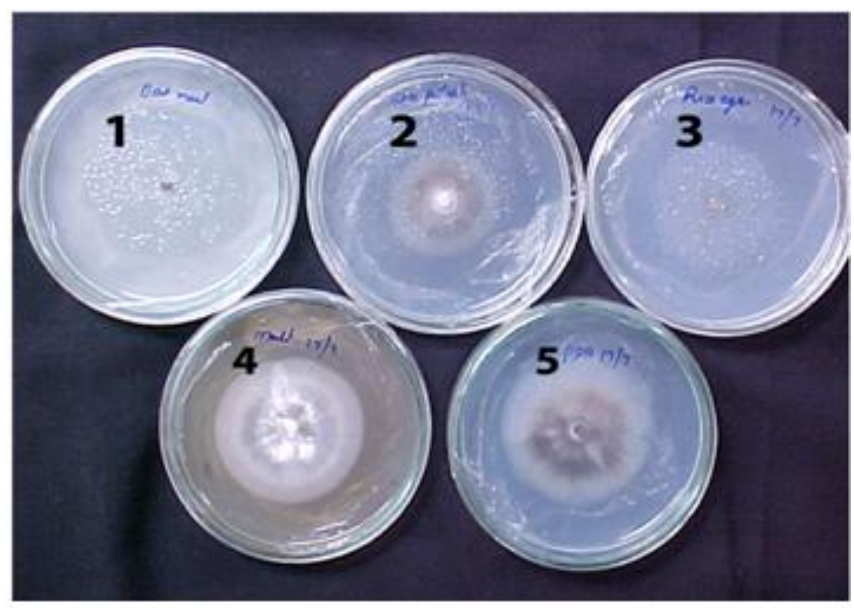

15th DAI

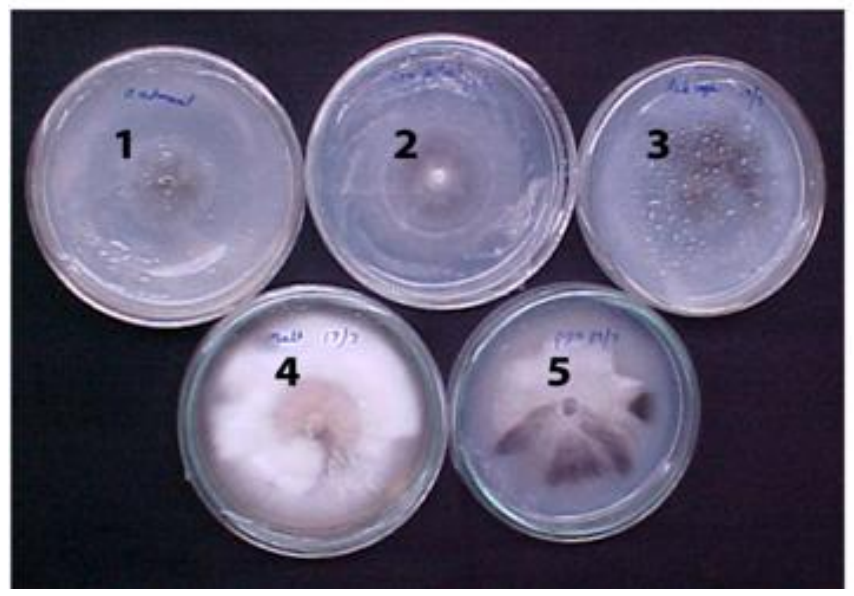

Figure 1. Growth of Coimbatore isolate of $P$. oryzae on different media. 1, Oat meal agar; 2, Rice agar; 3, Rice polish agar; 4, Malt extract agar; 5, Potato dextrose agar; DAl, Days after inoculation.

$0.5 \%$ SDS) and incubated at $65^{\circ} \mathrm{C}$ for $30 \mathrm{~min}$ followed by the addition of $1.7 \mathrm{M}$ potassium acetate solution. The contents were gently mixed and incubated at $-20^{\circ} \mathrm{C}$ for $30 \mathrm{~min}$. Samples were then extracted with equal volumes of chloroform and the total nucleic acid was precipitated with equal volumes of chilled isopropanol. The pellet after centrifugation was dried and dissolved in Tris-EDTA buffer $(10 \mathrm{mM}$ Tris and $1 \mathrm{mM}$ EDTA $(\mathrm{pH}: 8.0)$. The DNA was purified with phenol: chloroform $(1: 1 \mathrm{v} / \mathrm{v})$ and further using chloroform: isoamylalcohol $(24: 1 \mathrm{v} / \mathrm{v})$. Finally, the DNA was precipitated with chilled ethanol after adding $1 / 10^{\text {th }}$ volume of $3 \mathrm{M}$ sodium acetate. The DNA was dissolved in $50 \mu$ of TE buffer.

\section{Polymerase chain reaction (PCR)}

For PCR, the LTR1 (Long terminal repeat) primer designed from the LTR region of the Magnaporthe oryzae gypsy (MAGGY) retrotransposon sequence was used in combination with 7 ISSR (inter simple sequence repeat) primers as shown in Table 1.
REMAP amplification reactions were performed in $25 \mu \mathrm{l}$ reaction volume containing $1 \times$ Taq polymerase buffer $(10 \mathrm{mM}$ Tris $\mathrm{HCl}$ ( $\mathrm{pH}: 8.3), 50 \mathrm{mM} \mathrm{KCl}, 2.5 \mathrm{mM} \mathrm{MgCl}, 0.01 \%$ gelatin), 0.5 unit Taq polymerase, $150 \mu \mathrm{M}$ of each dNTP, $0.4 \mu \mathrm{M}$ LTR 1 primer, $0.6 \mu \mathrm{M}$ of ISSR primer and $50 \mathrm{ng}$ of template DNA. PCR was carried out in a PTC $-100^{\mathrm{TM}}$ programmable thermal controller (MJ. Research, Inc., Watertown, USA). The amplification profile consisted of initial denaturation at $92^{\circ} \mathrm{C}$ for $5 \mathrm{~min}$, followed by 40 cycles of $92^{\circ} \mathrm{C}$ for 45 $\mathrm{s}, 55^{\circ} \mathrm{C}$ for $45 \mathrm{~s}$ and $72^{\circ} \mathrm{C}$ for $1 \mathrm{~min}$ and a final extension of $72^{\circ} \mathrm{C}$ for 10 min. Amplified products were electrophoresed in $2 \%$ agarose gel and documented in an Alpha Imager (Alpha Innotech Corporation, San Leandro, CA, USA).

\section{Band scoring and data analysis}

The reproducibility of DNA profiles was verified by repeating the amplification with each of the selected primers. Only reproducible bands were considered for analysis. A negative control without DNA template and DNA from Rhizoctonia solani was also included in all the reactions. Each identifiable amplification product was considered as a DNA marker and scored for its presence or absence among the isolates.

\section{Cluster analysis}

The presence or absence of bands was converted into binary data ( 1 for presence and 0 for absence of each band) to determine the genetic relationship among the isolates. Similarity matrices were calculated with Jaggard's coefficient and the SIMQUAL program of NTSYS-pc (Exeter software, Setauket, NY, USA). Cluster analysis was done within the SAHN program by using the unweighted pairgroup method with arithmetic averages (UPGMA) method.

\section{RESULTS}

\section{Media suitable for culturing $\boldsymbol{P}$. oryzae}

The growth of $P$. oryzae was rapid on PDA followed by malt extract agar (Table 2 and Figure 1). At $5 \mathrm{DAl}$, the colony diameter was $3.60 \mathrm{~cm}$ on PDA which significantly differed from others. The fungus attained the full 9-cm-dia growth in PDA and malt extract agar at 15 DAl. On the same day, the growth on rice agar $(7.75 \mathrm{~cm})$ was on par with rice polish agar $(6.55 \mathrm{~cm})$. At $25 \mathrm{DAl}$, the colony diameter of the fungus was $9.0 \mathrm{~cm}$ in all the media except oatmeal agar.

\section{Spore induction on host bits}

Spore density was more when $P$. oryzae was multiplied on maize followed by rice stem in all the three observation intervals (Table 3 ). Production of conidia increased over time on maize as well as rice stem pieces. On maize, it was $475,1950,3420$ at 5,10 and 15 DAl respectively. However, spores could not be observed on $P$. repens at $5 \mathrm{DAl}$, though it was 200 and 500 at 10 and 15 DAI respectively. 
Table 1. Primer used for the study.

\begin{tabular}{ll}
\hline Primer & Primer sequence \\
\hline Forward - LTR1 & $5^{\prime}$-TGTCACAGACCTGAAGAACA-3' \\
Reverse - ISSR1 & $(\mathrm{AG})_{8} \mathrm{C}$ \\
ISSR2 & $(\mathrm{GA})_{8} \mathrm{C}$ \\
ISSR3 & $(\mathrm{GA})_{8} \mathrm{~A}$ \\
ISSR4 & $(\mathrm{AC})_{8} \mathrm{G}$ \\
ISSR5 & $(\mathrm{CA})_{8} \mathrm{~A}$ \\
ISSR6 & $(\mathrm{CA})_{8} \mathrm{GT}$ \\
ISSR7 & $(\mathrm{CA})_{8} \mathrm{GC}$ \\
\hline
\end{tabular}

Table 2. Evaluation of culture media for the growth of Pyricularia oryzae.

\begin{tabular}{lcccccc}
\hline \multirow{2}{*}{ Medium } & \multicolumn{7}{c}{ Colony diameter (cm) } \\
\cline { 2 - 7 } & $\mathbf{5}$ & $\mathbf{1 0}$ & $\mathbf{1 5}$ & $\mathbf{2 0}$ & $\mathbf{2 5}$ & $\mathbf{3 0}$ \\
\cline { 2 - 7 } & $3.60^{\mathrm{a}}$ & $6.25^{\mathrm{a}}$ & $9.00^{\mathrm{a}}$ & $9.00^{\mathrm{a}}$ & $9.00^{\mathrm{a}}$ & $9.00^{\mathrm{a}}$ \\
Potato dextrose agar & $(1.37)$ & $(2.50)$ & $(3.00)$ & $(3.00)$ & $(3.00)$ & $(3.00)$ \\
& $0.00^{\mathrm{c}}$ & $0.80^{\mathrm{d}}$ & $2.75^{\mathrm{d}}$ & $5.50^{\mathrm{c}}$ & $7.90^{\mathrm{b}}$ & $9.00^{\mathrm{a}}$ \\
Oat meal agar & $(0.22)$ & $(0.89)$ & $(1.65)$ & $(2.34)$ & $(2.93)$ & $(3.00)$ \\
& $2.85^{\mathrm{b}}$ & $5.00^{\mathrm{bc}}$ & $7.75^{\mathrm{b}}$ & $9.00^{\mathrm{a}}$ & $9.00^{\mathrm{a}}$ & $9.00^{\mathrm{a}}$ \\
Rice agar & $(1.29)$ & $(2.23)$ & $(2.78)$ & $(3.00)$ & $(3.00)$ & $(3.00)$ \\
& $2.95^{\mathrm{b}}$ & $4.80^{\mathrm{bc}}$ & $6.55^{\mathrm{b}}$ & $9.00^{\mathrm{a}}$ & $9.00^{\mathrm{a}}$ & $9.00^{\mathrm{a}}$ \\
Rice polish agar & $(1.29)$ & $(2.23)$ & $(2.78)$ & $(3.00)$ & $(3.00)$ & $(3.00)$ \\
Malt & $3.00^{\mathrm{b}}$ & $5.50^{\mathrm{b}}$ & $9.00^{\mathrm{a}}$ & $9.00^{\mathrm{a}}$ & $9.00^{\mathrm{a}}$ & $9.00^{\mathrm{a}}$ \\
extract agar & $(1.73)$ & $(2.34)$ & $(3.00)$ & $(3.00)$ & $(3.00)$ & $(3.00)$ \\
\hline
\end{tabular}

Means in columns followed by the same letter are not significantly different $(P<0.05)$ according to DMRT. Figures in the parentheses are square root transformed values.

Table 3. Assessment of spore density on stem bits

\begin{tabular}{lccc}
\hline Medium & \multicolumn{3}{c}{ Number of spores / ml of water } \\
\cline { 2 - 4 } & $\mathbf{5}$ & Days after inoculation \\
\cline { 2 - 4 } & 475 & 10 & $\mathbf{1 5}$ \\
\hline Maize & 100 & 400 & 3420 \\
Rice & & 200 & 700 \\
Panicum repens & - & & 500 \\
\hline
\end{tabular}

\section{Measurement of spore size}

The length and width of the conidia of different isolates of $P$. oryzae (Figure 2) were measured (Table 4). The mean length of the spores of the isolate from $P$. purpureum significantly differed from all others. The spore length of Coimbatore isolate was $22.7 \mu \mathrm{m}$. Spores of Sathyamangalam leaf and neck, Gudalore, Pakkapatti, Veeranam, Thoothukudi and E.colonum isolates were on par. The spore length was 20.5 and $20.4 \mu \mathrm{m}$ for Erode and Gopichettipalayam isolates respectively.

The mean width of spores of the isolate from $P$. purpureum was significantly different $(9.9 \mu \mathrm{m})$ from others. The isolates from Coimbatore, Sathyamangalam leaf and neck, Gudalore, Pakkapatti, Veeranam and Thoothukudi and E. colonum were on par. The width of the spores was minimum $(7.8 \mu \mathrm{m})$ in Erode and Gopichettipalayam isolates. 

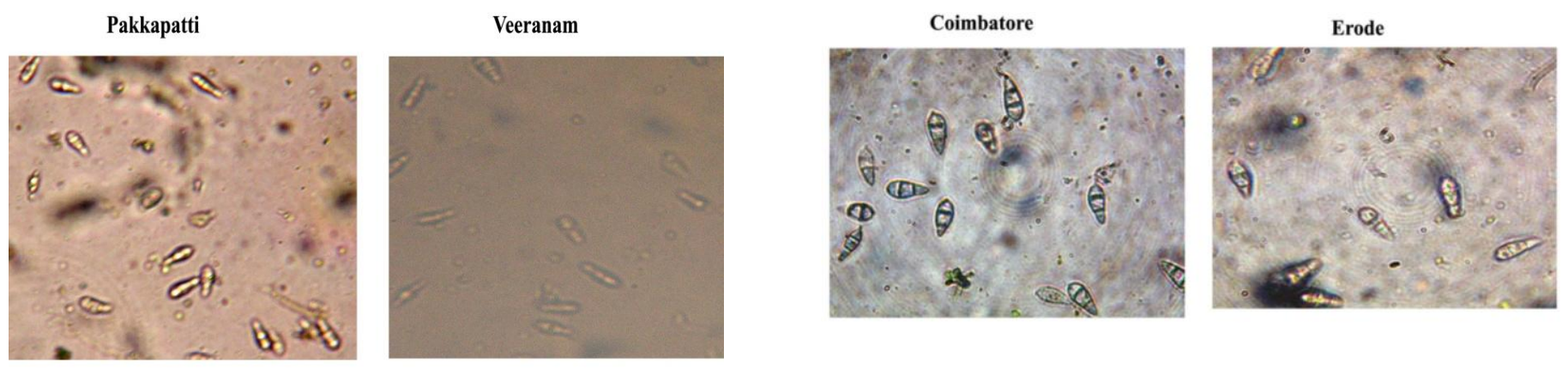

Sathyamangalam

Thoothukudi

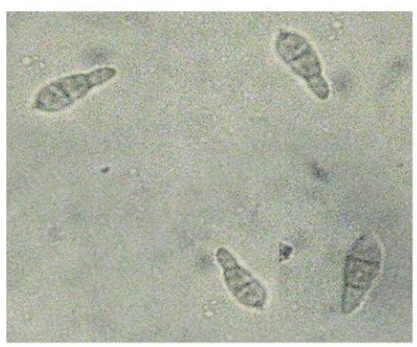

Echinochloa colonum

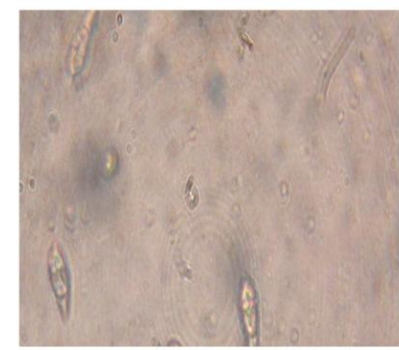

Pennisetum purpureum

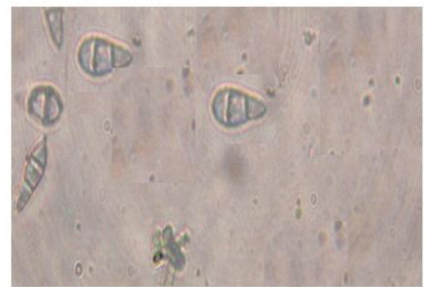

Figure 2. Conidia of different isolates of $P$. oryzae.

\section{Variability studies by using molecular markers}

Eleven (11) isolates of $P$. oyzae including two from nonrice hosts were subjected to REMAP analysis and the results are presented in Table 5. The size of the amplification products varied between 0.1 to $2 \mathrm{~kb}$. A total of 75 scorable bands were detected, of which all were found to be polymorphic. The REMAP patterns exhibited a high level of polymorphism. The REMAP fingerprinting was distinct and clear with primer combinations of LTR1 + $(\mathrm{GA})_{8} \mathrm{~A}$ and LTR1 + $(\mathrm{AC})_{8} \mathrm{G}$ (Figure 3). There was no amplification with $R$. solani and control without DNA template in all the REMAP analysis (results displayed by other primer combinations are not shown).

When LTR1 was used in combination with $(A G)_{8} C$, Erode, Gopichettipalayam and Veeranam, isolates were monomorphic with a single amplicon of $\sim 100$ bp while others were polymorphic (figures not shown). Gudalore,
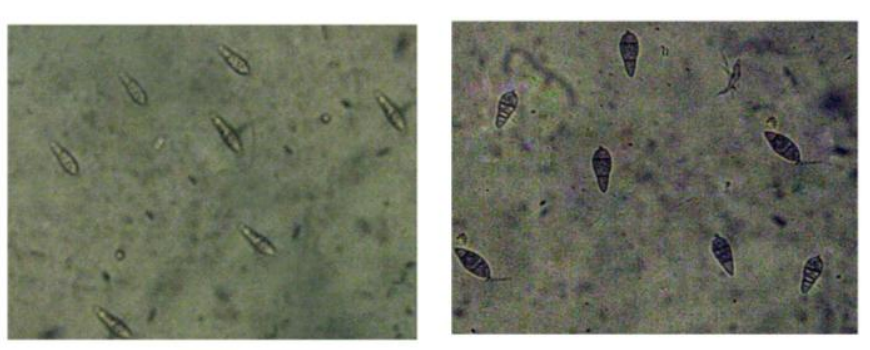

Gopichettipalayam
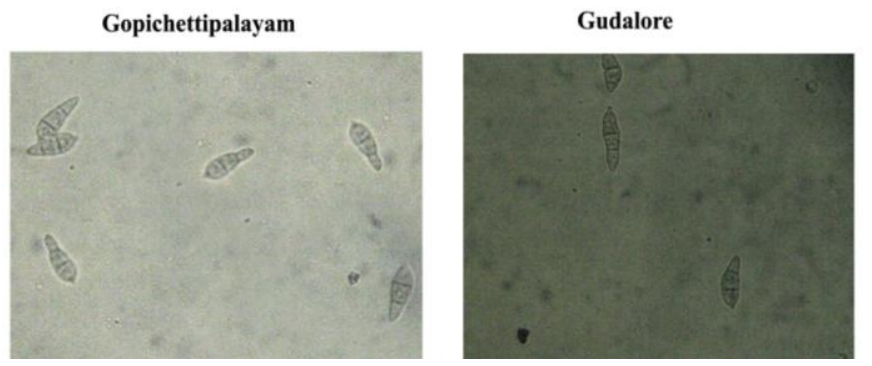

Figure 2. Contd.

Pakkapatti and Thoothukudi isolates did not show any amplification. With the primer combination of LTR1 and $(\mathrm{GA})_{8} \mathrm{C}$, Erode and Gopichettipalayam isolates showed a similar fingerprinting pattern. The leaf and neck isolates of Sathyamangalam appeared similar with multiple bands. Veeranam and Pakkapatti isolates of Tirunelveli district were similar with 170 and 200 bp products. Fingerprintings were observed with all isolates except the one from Thoothukudi. The use of LTR1 and $(\mathrm{GA})_{8} \mathrm{~A}$ resulted in amplification of all the rice isolates and the non-rice isolate from $E$. colonum (Figure 1). A single $200 \mathrm{bp}$ product was exhibited by Erode and Gopichettipalayam isolates. Veeranam and Pakkapatti isolates showed similar banding pattern with 170 and 200 bp products.

However, variations were observed in the other isolates. Erode and Gopichettipalayam isolates got amplified with a single band with the primer combination of LTR1 and $(\mathrm{AC})_{8} \mathrm{G}$ (Figure 4). Gudalore and Thoothukudi isolates were similar with two markers of $\sim 100$ and $200 \mathrm{bp}$. 
Table 4. Length and width of the spores of different isolates of Pyricularia oryzae $(\mu \mathrm{m})$.

\begin{tabular}{lcccc}
\hline \multirow{2}{*}{ Isolate } & \multicolumn{2}{c}{ Length } & \multicolumn{2}{c}{ Width } \\
\cline { 2 - 5 } & Range & Mean & Range & Mean \\
\hline Coimbatore & $20.0-25.0$ & $22.7^{\mathrm{b}}$ & $7.7-8.5$ & $8.2^{\mathrm{b}}$ \\
Erode & $18.3-22.0$ & $20.5^{\mathrm{d}}$ & $7.1-8.3$ & $7.8^{\mathrm{c}}$ \\
Gopichettipalayam & $18.1-22.2$ & $20.4^{\mathrm{d}}$ & $7.0-8.3$ & $7.8^{\mathrm{c}}$ \\
Sathyamangalam & $19.2-23.3$ & $21.6^{\mathrm{c}}$ & $7.7-8.7$ & $8.3^{\mathrm{b}}$ \\
Sathyamangalam(neck) & $20.0-24.0$ & $21.8^{\mathrm{c}}$ & $7.5-8.5$ & $8.0^{\mathrm{b}}$ \\
Gudalore & $19.2-23.6$ & $21.4^{\mathrm{c}}$ & $7.1-8.3$ & $8.2^{\mathrm{b}}$ \\
Pakkapatti & $20.0-22.5$ & $21.7^{\mathrm{c}}$ & $7.5-8.5$ & $8.0^{\mathrm{b}}$ \\
Veeranam & $19.8-22.3$ & $21.7^{\mathrm{c}}$ & $7.4-8.3$ & $8.1^{\mathrm{b}}$ \\
Thoothukudi & $21.0-23.0$ & $21.5^{\mathrm{c}}$ & $7.5-8.5$ & $8.0^{\mathrm{b}}$ \\
Echinochloa colonum & $19.2-25.0$ & $22.0^{\mathrm{c}}$ & $8.3-8.7$ & $8.5^{\mathrm{b}}$ \\
Pennisetum purpureum & $23.3-27.0$ & $25.2^{\mathrm{a}}$ & $9.0-11.6$ & $9.9^{\mathrm{a}}$ \\
\hline
\end{tabular}

Data are the mean of ten spore. Means in columns followed by the same letter are not significantly different $(P<0.05)$ according to DMRT.

Table 5. PCR products displayed by REMAP technique.

\begin{tabular}{lcc}
\hline Primer combination & Total band & Polymorphic band \\
\hline LTR-1 $+(A G)_{8}$ C & 12 & 12 \\
LTR-1 $+(\mathrm{GA})_{8}$ C & 13 & 13 \\
LTR-1 $+(\mathrm{GA})_{8} \mathrm{~A}$ & 13 & 13 \\
LTR-1 $+(\mathrm{AC})_{8} \mathrm{G}$ & 10 & 10 \\
LTR-1 $+(\mathrm{CA})_{8} \mathrm{~A}$ & 7.0 & 7.0 \\
LTR-1 $+(\mathrm{CA})_{8} \mathrm{GT}$ & 10 & 10 \\
LTR-1 $+(\mathrm{CA})_{8} \mathrm{GC}$ & 10 & 10 \\
Total & 75 & 75 \\
\hline
\end{tabular}

Though the total DNA fingerprinting was not clear with LTR 1 and $(C A)_{8} A$, Erode and Gopichettipalayam showed single bands of $\sim 100 \mathrm{bp}$. The leaf and neck isolates of Sathyamangalam were also similar. When LTR1 and $(G A)_{8} G T$ were used, amplification was observed only in seven isolates, of which six showed a single band of varying size. Multiple bands were observed with Coimbatore isolate. The banding patterns with LTR1 and $(\mathrm{CA})_{8} \mathrm{GC}$ were not clear. However, Erode and Gopichettipalayam isolates showed similar fingerprinting patterns. Sathyamangalam leaf and neck isolates were also similar. The isolate from Veeranam and Pakkapatti exhibited a single DNA band. Phylogenetic model of the pooled data from REMAP markers out grouped R.solani (Table 6; Figure 4). Thoothukudi isolate of P.oryzae was highly variable with only $5 \%$ similarity with others. The remaining 10 isolates had $12 \%$ similarity. The isolates from Erode, Gopichettipalayam, Veeranam and Pakkapatti showed $15 \%$ similarity. Veeranam and Pakkapatti isolates grouped under one cluster with $75 \%$ similarity. Erode and Gopichettipalayam isolates were totally similar. The remaining isolates of rice and non-rice formed one cluster exhibiting $20 \%$ similarity. The isolates from $P$. purpureum and $E$. colonum formed one cluster with $27.6 \%$ similarity. The isolates causing leaf and neck blast from Sathyamangalam exhibited $52.9 \%$ similarity while $30 \%$ similarity was observed with Coimbatore, Sathyamangalam and Gudalore isolates.

\section{DISCUSSION}

Among the five natural media evaluated for culturing $P$. oryzae, the growth was fast on PDA, malt extract agar and slows on rice and rice polish agar. The growth was uniform in each of the natural medium. Leaver et al. (1947) compared the growth of $P$. oryzae on rice polish agar with synthetic media and observed uniform growth in chemically defined media compared to the natural medium. Kumar and Singh (1995) compared the growth of $M$. grisea collected from rice, finger millet and pearl millet on 20 different media including malt extract agar, PDA, oat meal agar, rice agar and rice polish agar that were used in our comparison also. Their experiment was 

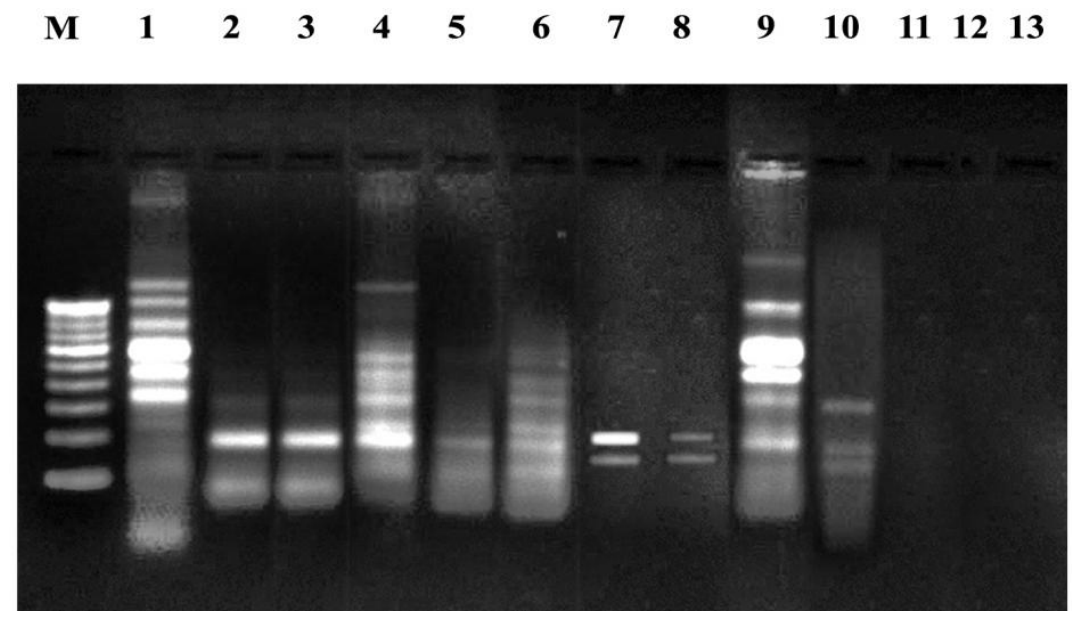

Figure 3a. Banding patterns generated by REMAP primer LTR-1 and (GA)8A.

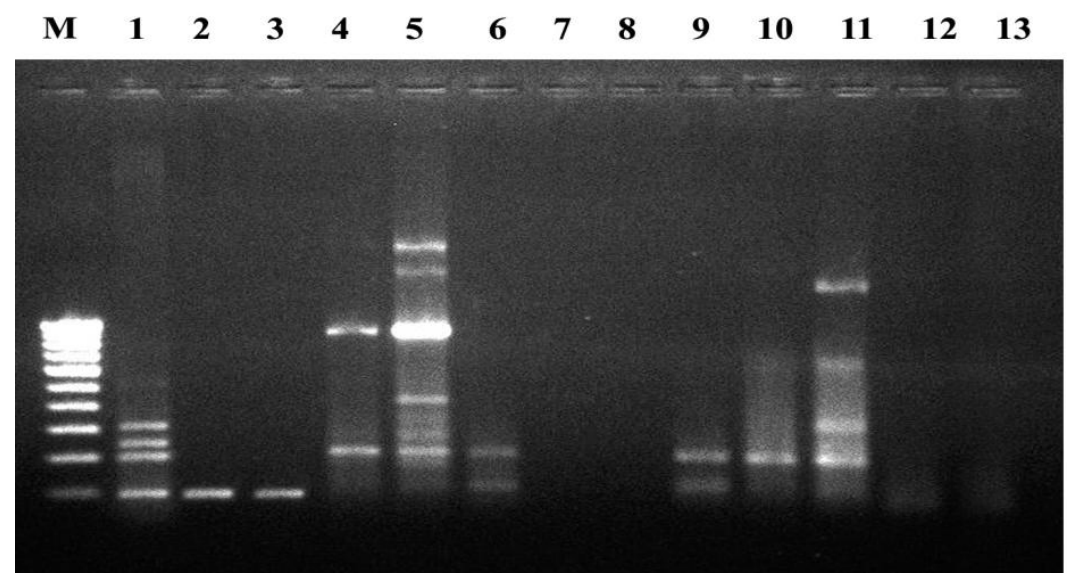

Figure $3 \mathrm{~b}$. Banding patterns generated by REMAP primer LTR-1 and (AC)8G. M- 100bp DNA ladder. Pyricularia oryzae isolates from: 1, Coimbatore; 2, Erode; 3, Gopichettipalayam; 4, Sathyamangalam; 5, Sathyamangalam (neck blast); 6, Gudalore; 7, Veeranam; 8, Pakkapatti; 9, Thoothukudi; 10, Echinochloa colonum; 11, Pennisetum purpureum; 12, Rhizoctonia solani; 13, control.

terminated on $8^{\text {th }}$ day and the maximum colony diameter of the rice isolate was on malt extract agar $(5.8 \mathrm{~cm})$ followed by PDA $(4.2 \mathrm{~cm})$ when incubated at $27 \pm 1^{\circ} \mathrm{C}$. In the present study, when the rice isolate (Coimbatore) was incubated at $28 \pm 2^{\circ} \mathrm{C}$, its growth on $10^{\text {th }}$ day was $5.5 \mathrm{~cm}$ on malt extract agar and $6.2 \mathrm{~cm}$ on PDA. Ou (1985) reports that morphology of $P$. oryzae is found to vary greatly with the medium and isolates used. In the present investigation, the mycelial color was white on polish rice, malt extract and oat meal agar, whitish grey on rice agar and grey on PDA. Flat growth was observed with rice, rice polish agar, oatmeal agar and PDA while it was fluffy on malt extract agar. However, when all the 11 isolates under study were tested on PDA, they were grey. Recently, Khadka et al. (2012) well studied and reported the differential responses of $P$. oryzae from different host plants and their growth characteristics in different nutrient media from Nepal.

Our repeated attempts to induce sporulation of $P$. oryzae on the surface of culture media were unsuccessful. Further, sporulation could not be induced by culturing the fungus on PDA followed by continuous exposure to fluorescent light for seven days as suggested by Srinivasachary et al. (2002). A simple way to induce sporulation was to grow the fungus on host stem pieces. Spores of $P$. oryzae isolate from $P$. purpureum were significantly bigger than the rice isolates. Among the rice isolates, the spores of Erode and Gopichettipalayam isolates were significantly smaller in size than that of the others. Ou (1985) states that the size of spores of the 


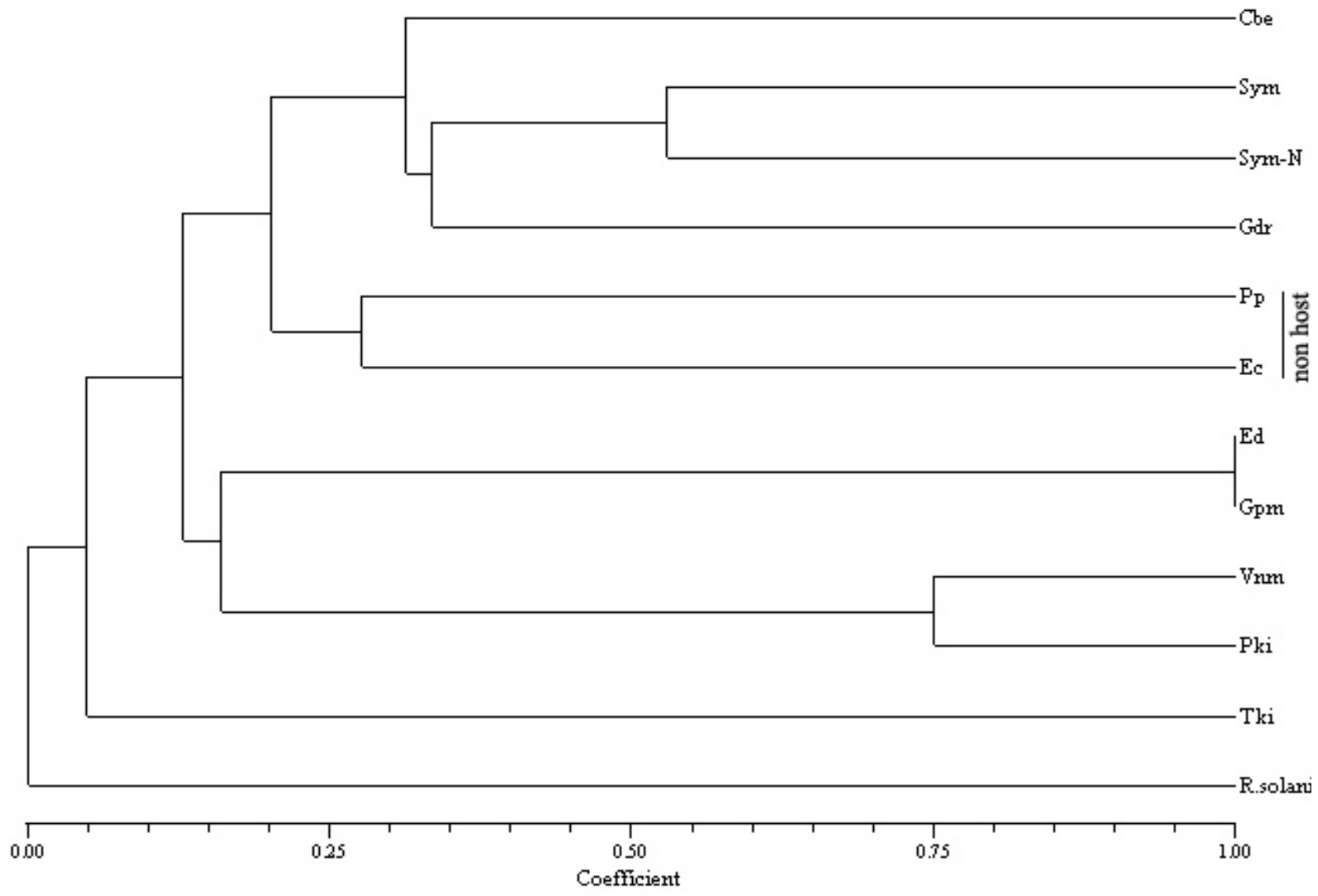

Figure 4. Dendrogram depicting the relationship of 11 isolates of Pyricularia oryzae based on DNA fingerprinting patterns generated by REMAP markers.

Table 6. Similarity matrix generated by REMAP analysis of Pyricularia oryzae isolates collected from different locations.

\begin{tabular}{lllllllllllll}
\hline Isolate & Cbe & Ed & Gpm & Sym & Sym-N & Gdr & Vnm & Pki & Tki & Ec & Pp & R.solani \\
\hline Cbe & 1.000 & & & & & & & & & & & \\
Erd & 0.120 & 1.000 & & & & & & & & & & \\
Gpm & 0.120 & 1.000 & 1.000 & & & & & & & & & \\
Sym & 0.385 & 0.118 & 0.118 & 1.000 & & & & & & & & \\
Sym-N & 0.228 & 0.091 & 0.091 & 0.529 & 1.000 & & & & & & & \\
Gdr & 0.327 & 0.148 & 0.148 & 0.382 & 0.286 & 1.000 & & & & & & \\
Vnm & 0.085 & 0.133 & 0.133 & 0.100 & 0.107 & 0.182 & 1.000 & & & & & \\
Pki & 0.082 & 0.188 & 0.188 & 0.094 & 0.100 & 0.167 & 0.750 & 1.000 & & & & \\
Tki & 0.067 & 0.077 & 0.077 & 0.034 & 0.037 & 0.095 & 0.000 & 0.000 & 1.000 & & & \\
Ec & 0.179 & 0.103 & 0.103 & 0.231 & 0.150 & 0.281 & 0.174 & 0.160 & 0.043 & 1.000 & & \\
Pp & 0.130 & 0.125 & 0.125 & 0.194 & 0.206 & 0.241 & 0.222 & 0.200 & 0.056 & 0.276 & 1.000 & \\
R.solani & 0.000 & 0.000 & 0.000 & 0.000 & 0.000 & 0.000 & 0.000 & 0.000 & 0.000 & 0.000 & 0.000 & 1.000 \\
\hline
\end{tabular}

Cbe, Coimbatore; Erd, Erode; Gpm, Gopichettipalayam; Sym, Sathiyamangalam; N, neck blast; Gdr, Gudalore; Vnm, Veeranum; Pki, Pakkapatti; Tki, Thoothukudi; Ec, Echinochloa colonum; Pp, Pennisetum purpureum.

blast fungus varies among the isolates depending on the environmental conditions.

Akoi (1985) measured the spore size of different isolates of $\mathrm{P}$. oryzae from rice cultured on PDA and reported that the average length ranged from 21.2 to $28.4 \mu \mathrm{m}$. In our study, the spore length of rice isolates of $P$. oryzae cultured on maize stem pieces ranged from $18.1 \mu \mathrm{m}$ to $25.0 \mu \mathrm{m}$. Kulkarni and Patel (1956) observed variations in 
spore length and width of $P$. setariae from Setaria italica due to the effect of artificial media. They also noticed that temperature had no effect on the width of the spore while length was affected. However, in our study, spores induced on maize stem pieces were measured for the rice and non-rice isolates of $P$. oryzae from $E$. colonum and $P$. purpureum.

Variability studies based on the phenotypic traits and virulence test using host differentials are highly inconsistent. Since molecular markers are direct manifestations of genetic make-up of any organism, they serve as reliable indices to study the population variability. Genome fingerprinting has a major role to study the variability of fungus. Techniques such as RFLP, RAPD, rep-PCR and REMAP have been used to study the population genetics of $M$.grisea (George et al., 1998; Kalender et al., 1999; Viji et al., 2000; Srinivasachary et al., 2002; Rathour et al., 2004b; Misra et al., 2005; Chadha and Gopalakrishna, 2005a; Chadha and Gopalakrishna, 2005b). Viji et al. (2000) were the first to study the DNA polymorphisms among the Indian isolates of $M$. oryzae from finger millet and rice using the probe MGR586. The finger millet infecting isolates were distinct with a single band, while the rice infecting ones showed 50-70 bands. The rice isolates were from Paiyur of Tamil Nadu and the others were from Nepal.

Fingerprinting of 48 rice isolates of $M$. grisea collected from Himachal Pradesh through RAPD was attempted by Rathour et al. (2004a) and high genetic diversity with $83 \%$ polymorphisms was observed. Further, no combination of resistance genes was found to confer resistance against all RAPD fingerprint groups of the pathogen population. Chadha and Gopalakrishna (2005a) also used RAPD technique to study the genetic diversity of the rice isolates of $M$. grisea collected from 12 different states of India including one from Pondicherry and the isolates were found to exhibit $64 \%$ polymorphism. However, their study did not include any isolate from Tamil Nadu. Though RAPD is a simple PCR based DNA fingerprinting technique, it uses 10 mer with low annealing temperature leading to results of low fidelity.

George et al. (1998) used rice and non-rice isolates of M. oryzae from Philippines and the Himalayas of India for studying the variability by rep-PCR utilizing sequence from the Pot 2 element. Fragments of DNA ranging from $400 \mathrm{bp}$ to $23 \mathrm{~kb}$ were amplified and the resulted grouping of isolates was comparable with that of MGR586 RFLP lineages. Populations from $P$. grisea from three blast epidemics that occurred in Orissa during 1997, 2000 and 2002 were compared by Misra et al. (2005). They concluded that traditional rice cultivars were infected by a single prominent lineage of the pathogen during epidemics, while modern rice cultivars were infected by multiple lineages. Initially, our repeated efforts of fingerprinting following the rep-PCR failed. Moreover, the technique requires 10 -min extension at $65^{\circ} \mathrm{C}$ in PCR cycle leading to extended duration of nearly $8 \mathrm{~h}$. Hence, we resorted to REMAP DNA fingerprinting.

Kalender et al. (1999) were the first to use REMAP technique to fingerprint variability in barley. Chadha and Gopalakrishna (2005b) applied this technique to study the population genetics of $M$. oryzae obtained from Pondicherry, Kerala, Gujarat, Maharastra, Orissa and Assam. The technique uses long terminal repeat primer based on the LTR region (253 bp of the MAGGY transposon) in combination with a primer designed for annealing at the $3^{\prime}$ end of a stretch of a SSR and detects retrotransposons inserted near SSRs. The high degree of polymorphism observed in the population of $M$. oryzae mentioned above was attributed to the actions of retrotransposon.

In this study, the primer combinations of LTR 1 and $(\mathrm{AC})_{8} \mathrm{G}, \mathrm{LTR} 1$ and $(\mathrm{GA})_{8} \mathrm{~A}$ yielded better results. Clear fingerprinting pattern was also obtained with the same set of primers as suggested by Chadha and Gopalakrishna (2005b). We observed high level of variability with only $5 \%$ similarity among the rice and non-rice isolates. Our results lend support to the earlier findings that Indian isolates of rice blast pathogen are highly variable (Chadha and Gopalakrishna, 2005b; Rathour et al., 2004b; Srinivasachary et al., 2002). Based on the present study, it can be concluded that the Tamil Nadu isolates of $P$. oryzae are genetically variable and their relationship can be studied reliably by REMAP markers

\section{REFERENCES}

Akoi $Y$ (1935). On physiologic specialization in rice blast fungus, Piricularia oryzae Br. et Cav. Ann. Phytopath. Soc. Jpn. 2: 107-120.

Anonymous (2005). Production Oriented Survey. Annu Repts. 19752005. Directorate of Rice Research, Hyderabad, India.

Babujee L, Gnanamanickam S (2000). Molecular tools for characterization of rice blast pathogen (Magnaporthe grisea) population and molecular marker-assisted breeding for disease resistance. Curr. Sci. 78: 248-257.

Barman RS, Chattoo BB (2005). Rice blast fungus sequenced. Curr. Sci. 89: 930-931.

Bonman JM, Bandong JM, Lee EJ, Valent B (1989). Race specific partial resistance to blast in temperate Japonica rice cultivars. Plant Dis. 73: 496-499.

BPS, Badan Pusat Statistika (2008). Statistika Indonesia. Badan Pusat Statistika, Jakarta.

Chadha S, Gopalakrishna T (2005a). Genetic diversity of Indian isolates of rice blast pathogen (Magnaporthe grisea) using molecular markers. Curr. Sci. 88:1466-1469.

Chadha S, Gopalakrishna T (2005b). Retrotransposon-microsatellite amplified polymorphism (REMAP) markers for genetic diversity assessment of the rice blast pathogen (Magnaporthe grisea). Genome, 48: 943-945.

Choi J, Park SY, Kim BR, Roh JH, Oh IS, Han SS, Lee YH (2013). Comparative Analysis of Pathogenicity and Phylogenetic Relationship in Magnaporthe grisea Species Complex. PLoS ONE 8(2): e57196. doi:10.1371/journal.pone.0057196.

George MLC, Nelson RJ, Zeigler RS, Leung H (1998). Rapid population analysis of endogenous repetitive DNA sequences. Phytopathology 88: 223-229.

Jo YK, Wang GL, Boehm MJ (2007). Expression analysis ofrice defense-related genes in turfgrass in response to Magnaporthe- 
grisea. Phytopathology 97:170-178.

Kalender R, Grob T, Regina MT, Suoniemi A, Schulman AH (1999). IRAP and REMAP: two new retrotransposon-based DNA fingerprinting techniques. Theoretical and Applied Genetics, 98: 704-711.

Khadka RB, Shrestha SM, Manandhar HK, Gopal BKC (2012). Study on Differential Response of Pyricularia grisea Isolates from Rice, Finger Millet and Panicum sp. with Local and Alien Media, and Their Host Range. Nepal J. Sci. Technol. 13(2):7-14.

Koutroubas SD, Katsantonis D, Ntanos DA, Lupotto E (2009). Blast disease influence on agronomic and quality traits of rice varieties under Mediterranean conditions. Turk. J. Agric., 33: 487-494.

Kulkarni NB, Patel MK (1956). Study of the effect of nutrition and temperature on the size of spores in Piricularia setariae. Indian Phytopath. 9: 33-38.

Kumar A, Singh RA (1995). Differential response of Pyricularia grisea isolates from rice, finger millet and pearl millet to media, temperature, $\mathrm{pH}$ and light. Indian J. Mycol. PI. Pathol. 25: 238-242.

Leaver FW, Leal J, Brewer CR (1947). Nutritional studies on Piricularia oryzae. J. Bacteriol. 54: 401-408.

Misra D, Singh UD, Dash AB, Reddy JN, Sridhar R (2005). Analysis of Pyricularia grisea populations from three different blast epidemics. International Rice Research Newsletter, 31: 22-23.

Mousanejad S, Alizadeh A, Safaie N (2010). Assessment of yield loss due to rice blast disease in Iran. J. Agr. Sci. Tech. Vol. 12: 357-364.

Ou SH (1985). Rice Diseases. Commonwealth Mycological Institute, Kew, U.K.

Padmanabhan SY (1965). Estimating losses from rice blast in India. In: Rice blast disease. Johns Hopkins Press, Mayland, Baltimore, USA. pp. 203-221.

Padmanabhan SY, Chakrabarti NK, Mathur SC, Veeraraghavan J (1970). Identification of pathogenic races of Pyricularia oryzae Cav. in India. Phytopathology 60: 1574-1577.

Rahim H (2010). Genetic studies on blast disease (Magnaporthe grisea) resistance in Malaysian rice. Universiti Kebangsaan, Selangor

Rajarajeswari NVL, Muralidharan K (2006). Estimates of farm yields and district production loss from rice blast epidemics. J. Mycol. Plant Pathol. 36:115-124.

Rathour R, Singh BM, Sharma TR (2004a). Sexual fertility in Magnoporthe grisea isolates from rice, finger millet and crabgrass in Himachal Pradesh. J. Mycol. Plant Pathol. 34: 230-232. Differentiate with $a$ and $b$.
Rathour R, Singh BM, Sharma TR, Chauhan RS (2004b). Population structure of Magnaporthe grisea from North -Western Himalayas and its implications for blast resistance breeding of rice. J. of Phytopathol. 152: 304-312. Differentiate with $a$ and $b$

Reis EM, Casa RT (2005). Doenças do trigo. Pages 631-638 in: Manual de Fitopatologia. Doenças de Plantas Cultivadas. Kimati $\mathrm{H}$, Amorim L, Rezende JAM, Bergamin A, Filho, Camargo LEA, eds. Ceres, São Paulo, Brazil.

Shim HS, Hong SJ, Yeh WH, Han SS, Sung JM (2005). Damage analysis of rice panicle blast on disease occurrence time and severity. J. Plant. Pathol. 21: 87-92.

Singh R, Sunder S, Dodan DS (2004). Evaluation of scented rice to blast and its management with fungicides. J. Mycol. Plant. Pathol. 34: 280.

Srinivasachary HS, Shivayogi S, Vaishali MG, Shashidhar HE, Girishkumar K (2002). Genetic analysis of rice blast fungus of Southern Karnataka using DNA markers and reaction of popular rice genotypes. Curr. Sci. 82: 732-735.

Teng PS, Torres CQ, Nuque FL, Calvera SB (1990). Current knowledge on crop losses in tropical rice. In: Crop loss assessment in rice. International Rice Research Institute, Los Banos, The Phillipines.

Tosa Y, Hirata K, Tamba H, Nakagawa S, Chuma I, Isobe C, Osue J, Urashima AS, Don LD, Kusaba M, Nakayashiki H, Tanaka A, Tani T, Mori N, Mayama S (2004). Genetic constitution and pathogenicity of Lolium isolates of Magnaporthe oryzae in comparison with host species-specific patho-types of the blast fungus. Phytopathology 94:454-462.

Viji G, Gnanamanickam SS, Levy M (2000). DNA polymorphisms of isolates of Magnaporthe grisea from India those are pathogenic to finger millet and rice. Mycol. Res. 104: 161-167. 